\title{
Faculty members' planned technology integration behaviour in the context of a faculty technology mentoring programme
}

\author{
Hatice Cilsalar Sagnak \\ Yozgat Bozok University \\ Evrim Baran \\ Iowa State University
}

\begin{abstract}
This qualitative case study aimed to examine faculty members' perceived behaviour regarding the use of technology in their classrooms. The behavior was examined within the framework of the decomposed theory of planned behavior. The theory states that technology integration behaviour is directly related to intention and perceived behaviour control and indirectly related to attitude, subjective norms and perceived behaviour control. Data sources included semi-structured interviews conducted with 17 faculty members who participated in a faculty technology mentoring programme implemented at a large public university in Turkey over a semester of 4 months' duration. The data analysis revealed that the factors affecting faculty members' planned technology integration behaviour were related to their intentions, attitude, subjective norms and perceived behaviour control, as explained in the theory. Faculty members identified a number of student-related, faculty-related and contextrelated challenges in technology integration. The recommendations arising from the study are to support and sustain faculty members' technology integration in higher education classrooms.
\end{abstract}

Implications for practice or policy:

- Technology mentoring programs can improve faculty teaching practices with technology in higher education classrooms.

- Faculty members' technology integration behaviour can be supported by addressing the challenges, including lack of time and motivation, insufficient technological knowledge and classroom management problems.

- The technology integration awareness of faculty members can be developed by improving the teaching and learning environment with the support of administrators, peers and students and providing the required time and incentives to integrate technology.

Keywords: technology integration, technology mentoring, faculty member, professional development, faculty mentoring

\section{Introduction}

Higher education institutions are undergoing dramatic changes concerning the design of learning experiences for university students. Technologies such as learning management systems (LMSs) and student response systems (SRSs) are common in many institutions and have received positive responses. To enhance students' learning in and outside of the classrooms, innovative instructional strategies are emerging, such as flipped learning (O’Flaherty \& Philips, 2015), massive open online courses (Jordan, 2014), blended learning (Motta, 2016) and mobile learning (Gikas \& Grant, 2013). Within this everchanging landscape, faculty members and academic staff with teaching and research responsibilities experience constant pressure to adopt new learning and pedagogical methods for their classrooms. While implementing these innovations, they encounter challenges such as poor administrative support (O'Flaherty \& Philips, 2015), negative attitudes (Prottas et al., 2016) and lack of knowledge of computer-based instruction (Marzilli et al., 2014). Problems related to time, access, space, supervision, operation and software (Gunuc, 2015), difficulties in curricular integration (Rivera, 2017) and a lack of technical support (Schoepp, 2004) were also noted. To break down these barriers, universities have implemented face-toface, online, synchronous, asynchronous, one-time and recurring professional development (PD) programmes, including self-directed learning experiences, professional meetings, seminars, workshops and conferences to accommodate faculty members' needs for effective technology integration in their classrooms (Johnson, 2015). The most common PD approaches, such as training, workshops and peer 
coaching models (Desimone \& Garet, 2015), have their own limitations as they may not not address faculty members' unique and contextual needs or they may require intensive voluntary effort for proper implementation (Kurtts \& Levin, 2000). An effective model to avoid these limitations is a faculty mentoring programme that provides one-to-one professional learning opportunities to faculty members with specific needs related to technology integration in their classrooms (Chuang et al., 2003). Informed by scholarly literature on PD supporting holistic development on technology integration (Kirkwood \& Price, 2013), faculty mentoring programmes ensure that faculty members receive immediate and individual support through extended and long-term engagement (Larson, 2009). They are generally designed with one-to-one working models with a younger adult who is an expert on educational technology, mentoring and guiding the faculty member in the process of planning, implementing and evaluating technology integration in their courses (Chuang et al., 2003).

With their mentors, faculty members participating in mentoring programmes are exposed to technologyenhanced pedagogical practices which enable them to improve their instructional approaches. Mentoring activities contribute to the development of faculty members' instructional strategies: (a) determining needs, (b) exploring technologies' affordances and limitations, (c) scaffolding, (d) sharing feedback, (e) connecting technology, pedagogy, and content, and (f) evaluating (Baran, 2016a, p. 56). With the inclusion of a facilitative environment, mentoring relationships, one-to-one communication channels and adequate support, technology mentoring programmes may help faculty members to strategically transform their technology integration behaviours. Additionally, the potential to appeal to their various needs and skills leverages the effectiveness of such programmes (Leh, 2005). These planned behavioural transitions can be understood and improved by examining various associated factors, such as self-efficacy and digital literacy, alongside an influential network of students, colleagues and friends (Buabeng-Andoh, 2012; Inan \& Lowther, 2010). Moreover, technical support, peer or student impact, administrative pressure, required time and technical inadequacy are other enabling or inhibiting factors that influence faculty members' planned technology integration behaviour (Mayes et al., 2015). It is therefore imperative to identify and discern enabling factors as well as eliminate inhibitors to enhance faculty members' behavioural performance on adopting technology integration practices.

This study used the decomposed theory of planned behaviour (DTPB; Taylor \& Todd, 1995) as a lens to examine the factors influencing faculty members' technology integration behaviour in their classrooms in the course of a technology mentoring programme. The factors affecting the behaviour correlate with each other in the DTPB. These correlations between the factors and behaviour are crucial for establishing measures to improve faculty members' performance on planned technology integration behaviour. Although there are substantial scholarly discussions involving behaviour, attitude and intention related to technology integration (Dupin-Bryant, 2012; Hassad, 2010; Wixom \& Todd, 2005), the literature on faculty members' technology integration behaviour in a mentoring programme context is limited (Sahin \& Thompson, 2007). Therefore, this study aimed to examine faculty members' perspectives on their changing behaviour to integrate technology with their classroom teaching in a technology mentoring programme. This study addressed the following research questions:

(1) How do the faculty members who participated in a technology mentoring programme perceive the factors related to their planned technology integration behaviour in the technology mentoring programme context?

(2) What are the challenges and possible solutions associated with the faculty members' technology integration into higher education classrooms within the technology mentoring programme context?

(3) What are the faculty members' perspectives who participated in the technology mentoring programme on the effectiveness of the programme?

\section{Theoretical background}

DTPB describes the rationale behind individuals' actions and the tendency to use information available to them to explain their behaviours, which are directed by their intentions (Taylor \& Todd, 1995). These behaviours are directly connected to intention towards behaviour and perceived behaviour of control and indirectly to attitude, subjective norms and perceived behaviour control (Ajzen, 2002). Understanding behaviour depends on the three main antecedents of intention - attitude, subjective norms and perceived behaviour control, which have their sub-dimensions (see Figure 1). 


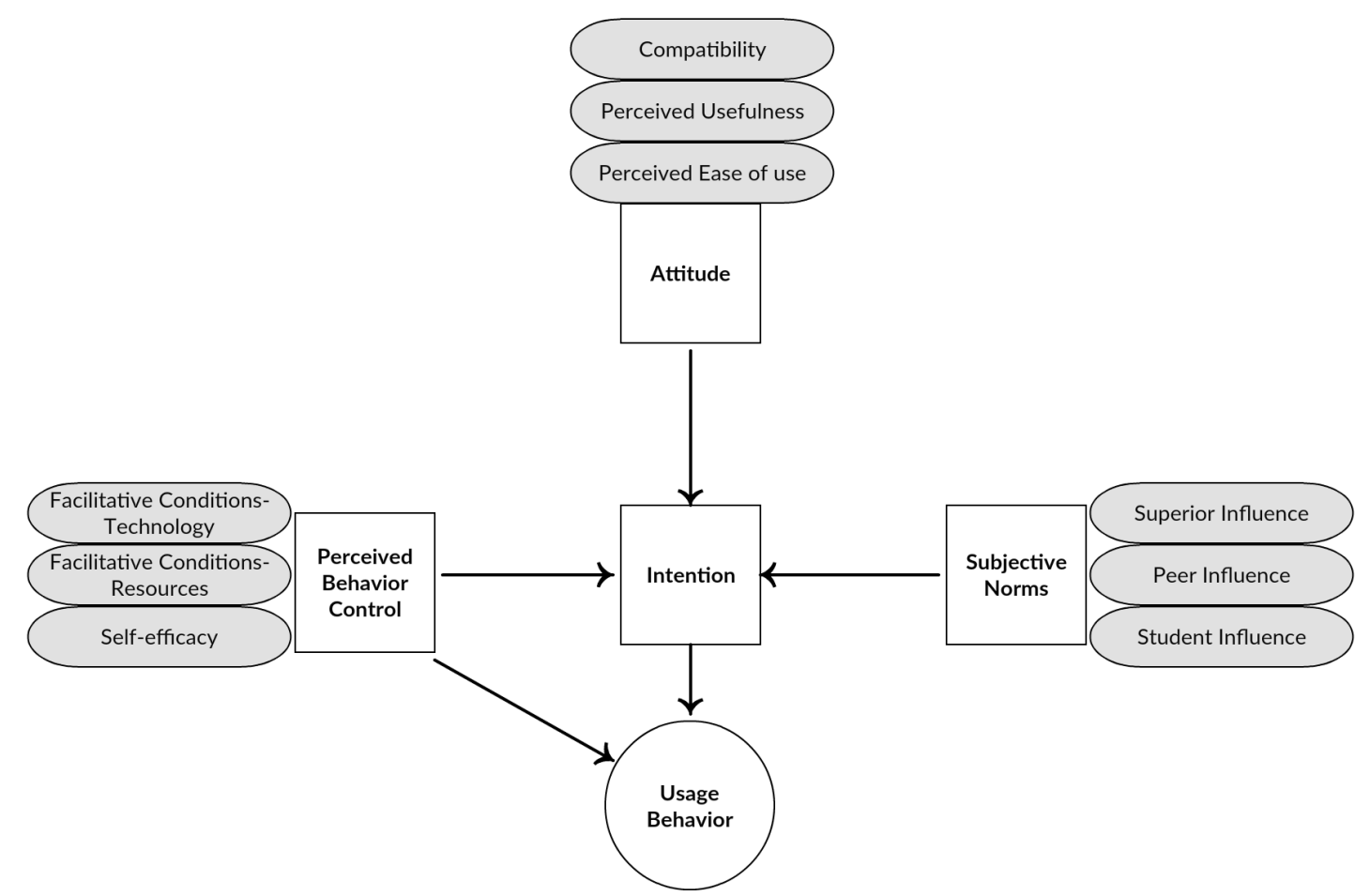

Figure 1. DTPB (source: Taylor and \& Todd, 1995, p. 146)

Attitude can be determined by perceived ease of use, perceived usefulness and compatibility. The first subdimension, perceived ease of use, is defined as "the degree to which a person believes that using a particular system would be free of effort" (Davis, 1989, p. 320), which is analogous to complexity. Perceived usefulness, the second sub-dimension, has an analogous term relative advantage, which is defined as "the degree to which a person believes that using a particular system would enhance his or her job performance" (Davis, 1989, p. 320). Perceived ease of use and perceived usefulness have a significant correlation with self-reported usage (Amoako-Gyampah, 2007). Briefly stated, the greater the expected benefits from the behaviour are, the easier it is to perform that behaviour. The third sub-dimension of attitude - compatibility - is defined as "the extent to which [an] innovation is perceived as consistent with existing values, past experiences, and needs of potential users" (Rogers, 1995, p. 224).

Subjective norms refer to the social pressure and influences that make an individual perform a particular behaviour (Ajzen, 1991). The management of behaviour performance in a context is influenced by the different opinions of the people around an individual, the ones who are given importance by the performer of the behaviour. Taylor and Todd (1995) classified these different groups of people as peers, students, colleagues, superiors, administrators and others. Only three main influential groups of individuals are considered for faculty members' technology integration: administrators, peers and students (Ajjan \& Hartshorne, 2008; Mouza, 2003), which comprised, also, the subjective norms in this study.

Perceived behaviour control directly contributes both to reveal the behaviour and to predict the behaviour and has its own three primary sub-dimensions: self-efficacy, facilitating resource conditions and facilitating technology conditions (Taylor \& Todd, 1995). Self-efficacy relates to confidence in the ability to behave successfully in a particular situation (Bandura, 1997). Self-efficacy has contributed considerably to the behaviour with perceived behaviour control (Taylor \& Todd, 1995). This means that the perception level of how well one performs the behaviour is directly proportional to the reliance on the performance of the behaviour and the proportion of actualisation of the behaviour (Atsoglou \& Jimoyiannis, 2012). The other sub-dimensions of perceived behaviour control are technology and resources as facilitative conditions that are factors in the behavioural context influencing a performer's eagerness. Thompson et al. (1991) defined facilitative conditions as the extent of influence of a factor in the environment on a teacher's decision to use technology. Technology integration behaviour is facilitated by the available technologies and resources, such as time, money, cooperation with others, computers, the Internet, technical and personal support, PD opportunities and technology skills. 
DTPB offers an opportunity to conceptualise the behaviours needed to design appropriate facilitative environments for teaching at a university and improve faculty members' planned technology integration behaviour (Ajjan \& Hartshorne, 2008). Results from previous studies with faculty members showed significant relationships among DTPB components such as behaviour-intention, intention-attitude (Lori et al., 2004), intention-subjective norms (Mak \& Ross, 2003) and intention-perceived behaviour control (Ajjan \& Hartshorne, 2008). Paver et al. (2014) concentrated on adjunct faculty members' technology use to support student learning and stressed the significant relationships among behaviour-intention, compatibility with attitude, self-efficacy with intention, subjective norms and all antecedents of it with intention.

Examining faculty members' planned technology integration behaviour in the context of a mentoring programme requires a close look into faculty members' perceptions of planned technology integration behaviour and the factors related to the behaviour, challenges and solutions in integrating technology in higher education. Furthermore, an effective mentoring programme for PD might create a facilitative environment for technology integration behaviour. Given that the technology integration behaviour development of faculty members has not been examined within a mentoring context, this research aims to contribute to the literature on faculty members' technology integration behaviour and faculty technology mentoring programmes. This study was conducted as part of a doctoral dissertation (Cilsalar, 2017).

\section{Method}

This qualitative case study aimed to develop an understanding of the contributions of a mentoring programme on the dimensions of technology integration behaviour through the process of educational technology exploration. The case comprised the experiences, thoughts and perceptions on technology integration of 17 faculty members after their participation in a mentoring programme involving 24 faculty members and 24 graduate students. Semi-structured interviews and mentors' case study reports were used to examine the factors affecting faculty members' technology integration to clarify the complexity of the technology integration phenomenon (Yin, 2003). The programme helped us to analyse the exploration process of technology integration of the faculty members who received professional support on educational technology for the first time.

\section{Context}

The technology mentoring programme was implemented at a large public university in Turkey as a oneon-one mentoring model. The university was selected for the study as it provided a wide range of educational technology services to faculty members and students, such as a computer centre, instructional technology support office and learning and student development office. During the programme, the university had just moved all courses to Moodle, a learning management system (LMS). All faculty members were encouraged to explore the new LMS platform as a support environment for their face-toface courses. The university's instructional technology support office and computer centre provided support for opening the courses on the LMS, carrying out workshops and assisting with technological problems. Volunteer graduate students in the Faculty of Education were chosen as mentors to guide the faculty members because of their relatively superior familiarity and efficiency with technology. The programme stressed the importance of establishing co-mentoring, a relationship where mutual benefit and shared responsibilities are emphasised.

The technology mentoring programme was implemented in the spring semesters of 2014 and 2015. The graduate students were invited to take the graduate course Technology and Teacher Education offered as a part of the Educational Sciences Graduate Programme. The mentors were graduates from a 4-year teaching programme proceeding with their graduate education in the Faculty of Education with the aim of becoming an academic. The students were offered the opportunity to participate in the faculty mentoring programme as mentors. To contribute to the mentors' technology integration skills, they explored technologies that can be implemented in teacher education. Although there was limited time to explore various instructional technologies, we developed the course content during the programme in parallel to the emergent demands of mentees during the mentoring programme. The students were paired with faculty members (mentees) and the mentor-mentee teams were expected to meet weekly and work on educational technology solutions within the faculty members' teaching contexts. The programme aimed to facilitate faculty members' technology integration with the assistance from mentors. The mentors were informed about the nature of 
and expectations from the mentorship before and during the mentoring programme as a part of the course. During the semester, mentors' meetings as a part of the course were organized each week to collectively share experiences gained during the mentorship and their feedback on other mentors' activities. These graduate students were expected to (a) determine the faculty members' needs, (b) search for ways to meet the needs, (c) determine possible technology integration strategies, (d) implement a technology integration plan, and (e) evaluate the implementation of technology integration and share the findings (Baran, 2016a). Faculty members' participation in the programme was completely voluntary. All participants received guidelines and policy on mentoring, which outlined mentoring procedure and basic expectations from their partnership. The steps were:

(1) Conducting needs analysis with faculty members at the beginning of the semester,

(2) Engaging in technology integration activities throughout the semester by holding weekly meetings and observing the faculty members' classes,

(3) Presenting technological and pedagogical solutions to problems laid out by faculty members,

(4) Exploring solutions through a collaborative discourse with faculty members and other mentors,

(5) Evaluating the results of implemented solutions, and

(6) Sharing the process and results with the community to disseminate the knowledge of innovations within the course (Baran, 2016a, p. 52).

The programme culminated at the end of the semester, with presentations of the pairs' journeys and mentors' case study papers.

\section{Participants}

The volunteer faculty members of the university participated in the mentoring program. Because of this, the sampling strategy of this study could be referred to as convenience sampling, although the selection of the participants was based on their willingness to participate. Although 24 faculty members (mentees) were enrolled in the programme, 17 of them (11 women, 6 men) from 13 departments agreed to participate in the research. Their ages ranged from 31 to 49 , and their teaching experience in higher education ranged from 2 to 22 years. These faculty members taught two or three courses during the technology mentoring programme, except two, who taught four courses. The number of enrolled students in these classes ranged from 30 to 230 . All the faculty members had already participated in at least one PD activity on technology integration. When labelling their expertise as novice, talented, skillful, proficient, advanced or expert, the labels of almost all centred between skilful and advanced, except for two participants, whose expertise was novice and talented (see Table 1). The participants reported that they were familiar mostly with technologies that were easily accessible at the campus as well as easy to manage, such as computer projection systems, LMS, file-sharing platforms, SRSs and social media. 
Table 1

Faculty member demographics

\begin{tabular}{|c|c|c|c|c|c|c|c|c|}
\hline Name* & Department & 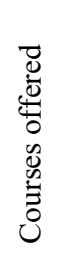 & 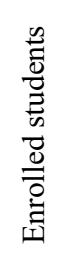 &  & 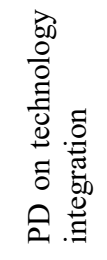 &  & 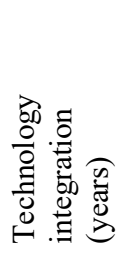 & $\begin{array}{l}\text { Faculty technology mentoring programme } \\
\text { activities }\end{array}$ \\
\hline Ali & Physics & 2 & 160 & 11 & 2 & 4 & 3 & $\begin{array}{l}\text { Already integrating technology what he } \\
\text { needs; developing pedagogical abilities in } \\
\text { class management }\end{array}$ \\
\hline Banu & Psychology & 2 & 180 & 4 & 2 & 2 & 4 & Needs assessment, SRS \\
\hline Baki & Sociology & 3 & 230 & 3 & 1 & 4 & 3 & Socrative, Kahoot, LMS \\
\hline Cansu & $\begin{array}{l}\text { Elementary } \\
\text { Science and } \\
\text { Mathematics } \\
\text { Education }\end{array}$ & 3 & 36 & 10 & 2 & 3 & 9 & Diigo, Kahoot, Socrative \\
\hline Deva & Industrial Design & 2 & 94 & 7 & 2 & 3 & 3 & LMS, Wordpress, Facebook \\
\hline Didem & $\begin{array}{l}\text { Educational } \\
\text { Sciences }\end{array}$ & 3 & 120 & 2 & 2 & 1 & 1 & Kahoot, Socrative \\
\hline Ela & $\begin{array}{l}\text { Business } \\
\text { Management }\end{array}$ & 4 & 200 & 10 & 1 & 3 & 10 & $\begin{array}{l}\text { Needs assessment, LMS, Turnitin, Diigo, } \\
\text { Pinterest, Infogram }\end{array}$ \\
\hline Figen & $\begin{array}{l}\text { Mechanical } \\
\text { Engineering }\end{array}$ & 2 & 65 & 2 & 2 & 3 & 2 & $\begin{array}{l}\text { Pre-survey to students, Prezi, clickers, } \\
\text { LMS }\end{array}$ \\
\hline Gül & $\begin{array}{l}\text { Educational } \\
\text { Sciences }\end{array}$ & 4 & 48 & 16 & 1 & 3 & 10 & $\begin{array}{l}\text { Needs assessment, Kahoot, Google } \\
\text { Communities, LMS }\end{array}$ \\
\hline Onur & $\begin{array}{l}\text { Electrical } \\
\text { Engineering }\end{array}$ & 2 & 90 & 2 & 2 & 5 & 2 & $\begin{array}{l}\text { Pre- and post-survey for student } \\
\text { satisfaction, Socrative, open educational } \\
\text { resources }\end{array}$ \\
\hline Orhan & $\begin{array}{l}\text { Educational } \\
\text { Sciences }\end{array}$ & 3 & 43 & 22 & 2 & 4 & 17 & Needs assessment, Socrative, blog \\
\hline Pelin & Economics & 2 & 100 & 7 & 1 & 3 & 2 & $\begin{array}{l}\text { Needs assessment, syllabus revision, use } \\
\text { LMS, exploration of Diigo \& } \\
\text { Letsfeedback }\end{array}$ \\
\hline Sadi & Chemistry & 3 & 120 & 5 & 1 & 5 & 4 & $\begin{array}{l}\text { Use Diigo and Socrative, exploration of } \\
\text { blogs }\end{array}$ \\
\hline Suat & $\begin{array}{l}\text { Electrical } \\
\text { Engineering }\end{array}$ & 2 & 30 & 2 & 2 & 3 & 2 & SRS with SMS/clickers, Prezi, LMS \\
\hline Seda & Economics & 2 & 130 & 7 & 2 & 3 & 3 & Needs assessment, blog, open courseware \\
\hline Serkan & $\begin{array}{l}\text { Industrial } \\
\text { Engineering }\end{array}$ & 2 & 50 & 7 & 2 & 3 & 1 & $\begin{array}{l}\text { Needs assessment, pre- and post-survey on } \\
\text { students' perceptions, Socrative, Kahoot, } \\
\text { Letsfeedback, Trello, Google Drive }\end{array}$ \\
\hline Yade & $\begin{array}{l}\text { Medical } \\
\text { Informatics }\end{array}$ & 3 & 40 & 20 & 1 & 4 & 15 & $\begin{array}{l}\text { Used LMS and Diigo; exploration of Prezi, } \\
\text { Camtasia, Captivate, Camstudio, } \\
\text { Facebook, Twitter, Socrative, clickers, } \\
\text { Letsfeedback }\end{array}$ \\
\hline
\end{tabular}

Note. *Pseudonyms reflecting their gender are used throughout the paper. ${ }^{* * 1}$ : Novice, 2: Talented, 3: Skillful, 4: Proficient, 5: Advanced, 6: Expert.

\section{Data collection}

Data sources included semi-structured interviews in Turkish conducted with faculty members after the semester they attended the programme. Each interview lasted approximately 45 minutes. The interview protocol included two main categories: initial background and main questions. The initial questions covered participants' educational and academic experience, opportunities to integrate technology (hardware, software, technical support) and possible changes to their courses after the technology mentoring programme. Some of the main questions were based on their experiences during the programme, the benefits and challenges of technology integration, contributions or inhibitions of individuals around them, 
specifically mentors, confidence in technology integration success and suggestions for development to other faculty members and the programme. The questions were selected to reveal their real-life experiences on technology integration because they already had some insights. They also concentrated on their practices during the programme and the benefits and challenges of technology integration while experiencing technology integration. Additionally, the participants received the demographic information form including questions related to age, gender, department, and frequently used technologies. The protocol and a consent form for the study were approved by the institutional ethical board. All participants signed the consent form before the interviews. Each interview was audio-taped and transcribed for further analysis.

\section{Data analysis}

All interview transcripts were analysed following the DTPB (Taylor \& Todd, 1995) framework as a lens to identify emerging patterns in the participants' behaviour performance. To interpret data for this research, the conceptual framework from the DTPB was used as a baseline to create an initial codebook.

During the first step of data analysis, some of the categories related to the research questions emerged, such as suggestions for the technology mentoring programme and student-related, instructor-related and contextrelated challenges of technology integration. The initial codebook was revised with the addition of the new categories. The categories that arose from data analysis process, suggested by Strauss and Corbin (1990), allowed using a pre-developed conceptual framework that can be revised combining predetermined as well as new concepts or themes and a general framework developed by the researcher. Before starting the final coding, the codebook was prepared, focusing on the definitions of terms coming from the DTPB.

All interviews were coded using Strauss and Corbin's (1990) data coding process. Open coding was performed first. Second, axial coding procedure (Burnaford, 2001) was performed to collapse similar and repetitive codes which help to identify patterns among participants (Taylor \& Bogdan, 2015). In the final stage, the codes were grouped by considering research questions and components of DTPB. In addition to the constructs of the DTPB, additional categories parallel to the research questions emerged in the second phase. To understand the patterns, themes and codes were counted and examined. A person not connected to the research transcribed the interviews conducted with the 17 faculty members, which we then coded separately. The coders' agreements and disagreements were counted to check inter-coder reliability, which indicated 81\% agreement - an acceptable level at the first step. After discussion on the codes, 97\% agreement was reached. Although there is no consensus on the standard for inter-coder reliability, a range of $67 \%-79 \%$ is considered acceptable in the field (Krippendorff, 2004); it was used in this study as a criterion for this type of reliability. The data analysis process took place throughout the study. The identified themes are shown in Table 2. In the first phase of data analysis, codes and themes arose from the theory itself. Analysis of all interviews was performed by using coding in a general framework method prescribed by Strauss and Corbin (1990), which allowed for using a pre-developed conceptual framework that could be revised with new concepts and themes to reach an in-depth understanding of the faculty members' technology integration behaviour. At the end of the first coding process, extra codes emerged from the data. By following the revised codebook, all transcriptions were re-coded in the second coding process. The connections between the codes were used to advance an understanding of the mentoring programme. All the analyses were performed in NVivo version 11 software, which helped to organize codes and themes during the data analysis process. Although all interviews were in Turkish, quotations in this research were translated into English by language experts. 
Table 2

Themes and codes and examples of the codes from data analysis

\begin{tabular}{|c|c|c|c|c|}
\hline Themes & $n$ & Definition & Sub-categories & Examples from data \\
\hline Behaviour & 16 & $\begin{array}{l}\text { The way in which faculty } \\
\text { member behaves or not } \\
\text { behave in response to } \\
\text { integrate technology. }\end{array}$ & $\begin{array}{l}\text { Experienced } \\
\text { Technologies, } \\
\text { Reasons to use, } \\
\text { Reasons not to } \\
\text { use }\end{array}$ & $\begin{array}{l}\text { Additionally, I am using LMS. I am using } \\
\text { to share PowerPoints, to make } \\
\text { announcements to students, to collect } \\
\text { homework. (Seda) }\end{array}$ \\
\hline Intention & 11 & $\begin{array}{l}\text { An act or instance of } \\
\text { determining mentally upon } \\
\text { integrating technology. }\end{array}$ & & $\begin{array}{l}\text { I always check the classroom before the } \\
\text { semester starts, whether there is computer } \\
\text { and projector. (Pelin) }\end{array}$ \\
\hline Attitude & 17 & $\begin{array}{l}\text { An expression of favor or } \\
\text { disfavor towards a person, the } \\
\text { degree to which performance } \\
\text { of the behaviour is positively } \\
\text { or negatively valued. A } \\
\text { feeling, belief, or opinion of } \\
\text { approval or disapproval } \\
\text { towards something. }\end{array}$ & $\begin{array}{l}\text { Compatibility, } \\
\text { Perceived } \\
\text { usefulness, } \\
\text { Perceived ease } \\
\text { of use }\end{array}$ & $\begin{array}{l}\text { I think it is a good application ... In time I } \\
\text { reconciled myself to educational } \\
\text { technologies, you know, I am not the fan of } \\
\text { technology in my daily life. I really like it } \\
\text { but it has not been a part of my life. (Banu) }\end{array}$ \\
\hline $\begin{array}{l}\text { Subjective } \\
\text { norm }\end{array}$ & 17 & $\begin{array}{l}\text { The perceived social pressure } \\
\text { or effect to perform or not to } \\
\text { perform technology } \\
\text { integration behaviour by } \\
\text { faculty members in terms of } \\
\text { student, peer, and } \\
\text { administrative influences }\end{array}$ & $\begin{array}{l}\text { Student } \\
\text { influence, Peer } \\
\text { influence, } \\
\text { Administrator } \\
\text { influence }\end{array}$ & $\begin{array}{l}\text { Everyone is dealing with mobile phones, } \\
\text { and I feel that asking how to take advantage } \\
\text { of this is compulsory for us. It is like } \\
\text { catching the era. (Serkan) }\end{array}$ \\
\hline PBC & 18 & $\begin{array}{l}\text { The perception of the ease or } \\
\text { difficulty of the technology } \\
\text { integration behaviour for } \\
\text { faculty members in terms of } \\
\text { self-efficacy and the } \\
\text { contribution or inhibition of } \\
\text { resources and technologies }\end{array}$ & $\begin{array}{l}\text { Self-efficacy, } \\
\text { Facilitative } \\
\text { conditions- } \\
\text { Resources, } \\
\text { Facilitative } \\
\text { conditions- } \\
\text { Technologies }\end{array}$ & $\begin{array}{l}\text { Once I taught in the central engineering } \\
\text { building, and there was a portable projector } \\
\text { and a curtain. In that classroom, the } \\
\text { projector did not reflect properly, and the } \\
\text { screen was seen in V or a trapezium shape. } \\
\text { Honestly, even I was uncomfortable. But in } \\
\text { time that disappeared. (Pelin) }\end{array}$ \\
\hline Challenges & 18 & $\begin{array}{l}\text { The problems/challenges } \\
\text { faced while the faculty } \\
\text { members integrated } \\
\text { technology in their } \\
\text { classrooms }\end{array}$ & $\begin{array}{l}\text { Student-related, } \\
\text { Instructor- } \\
\text { related, Context- } \\
\text { related }\end{array}$ & $\begin{array}{l}\text { I have problems with the Clicker system } \\
\text { because it allows me to ask limited } \\
\text { question types. I can only write text; I } \\
\text { cannot upload visuals. (Ali) }\end{array}$ \\
\hline Suggestions & 16 & $\begin{array}{l}\text { The ways to improve all } \\
\text { faculty members technology } \\
\text { integration behaviour and to } \\
\text { extend technology integration } \\
\text { to all classrooms at the } \\
\text { university }\end{array}$ & $\begin{array}{l}\text { Experience } \\
\text { sharing, increase } \\
\text { awareness, } \\
\text { seminars, need } \\
\text { for promotion, } \\
\text { etc. }\end{array}$ & $\begin{array}{l}\text { Faculty members need seminars } \\
\text { introducing the technologies which can be } \\
\text { used in higher education classes. (Onur) }\end{array}$ \\
\hline $\begin{array}{l}\text { Contribution } \\
\text { of technology }\end{array}$ & 17 & $\begin{array}{l}\text { The act of contributing to } \\
\text { instructional activities of } \\
\text { faculty members by solving } \\
\text { previous problems in or out } \\
\text { of classrooms }\end{array}$ & $\begin{array}{l}\text { Contribution to } \\
\text { instructor, } \\
\text { Contribution to } \\
\text { students }\end{array}$ & $\begin{array}{l}\text { I know that when I ask orally a question } \\
\text { those who are introverted would not answer } \\
\text { the question. Once I asked the question } \\
\text { through the system, they wrote their answer } \\
\text { and the answer rate increased suddenly. } \\
\text { (Banu) }\end{array}$ \\
\hline $\begin{array}{l}\text { Mentoring } \\
\text { programme }\end{array}$ & 17 & $\begin{array}{l}\text { The programme implemented } \\
\text { to contribute to faculty } \\
\text { members technology } \\
\text { integration behaviour with the } \\
\text { help of graduate students who } \\
\text { are mentors, in terms of } \\
\text { contributions of the } \\
\text { mentoring and suggestions to } \\
\text { improve it. }\end{array}$ & $\begin{array}{l}\text { Contributions of } \\
\text { the programme, } \\
\text { Suggestions to } \\
\text { improve the } \\
\text { programme }\end{array}$ & $\begin{array}{l}\text { This programme should be extended to } \\
\text { whole university. (Orhan) }\end{array}$ \\
\hline
\end{tabular}




\section{Trustworthiness}

Validity and reliability, which represent the worth of quantitative studies, are conceptualised in qualitative study as trustworthiness. To ensure trustworthiness (Lincoln, 2007), credibility, dependability and confirmability were checked and ensured. For this study, credibility was met by extended engagement of the researcher with data. To establish such engagement, data collection and data analysis processes were conducted simultaneously to understand the need for additional data. All data were analysed and interpreted line by line instead of summarising all of them. Peer feedback was obtained during the data analysis process.

Dependability was achieved through the description of the broader context for the concepts underlying the investigation. To support confirmability, the extent to which findings come from the data (Creswell, 2008), an audit trail was carried out in three ways. First, all raw data were kept as evidence to support the findings; second, all the data reduction and analyses products produced in NVivo version 11 were saved and printed out throughout the analysis process; and third, the data reconstruction and synthesis products, created with NVivo version 11, including the structure of the categories (themes, definitions and relationships) were printed and maintained.

\section{Results}

The results were classified into three categories related to the research questions, namely factors related to faculty members' planned technology integration behaviour, challenges and solutions that these faculty members faced when integrating technology within the technology mentoring programme context and evaluation of the technology mentoring programme. Sandelowski et al. (2009) reported that "quantizing" (p. 208) data in qualitative research is used "to facilitate pattern recognition or otherwise to extract meaning from qualitative data, account for all data, document analytic moves, and verify interpretations" (p. 210). To illustrate the emphasis given by the participants, the codes were represented with numbers in parentheses that refer to the number of the participants who cited the specific codes, although quantising can limit the meaning of qualitative data.

\section{Factors related to faculty members' planned technology integration behaviour}

\section{Behaviour}

The faculty members referred to all antecedents of DTPB in the interviews - intention, behaviour, attitude, subjective norms and PBC. Various behaviours during the technology mentoring programme were observed, such as using SRSs, LMSs, social media, blogs, electronic sources and web pages. LMSs and SRSs were the technologies most commonly mentioned. The faculty members indicated that they were using the previous version of the LMS or a similar platform for online management of instruction and learning before the programme. They first experienced the newly implemented LMS with guidance from their mentors. To increase student engagement and take advantage of students' mobile phone usage in the classroom, the faculty members preferred to integrate SRSs. Ela indicated the reason she used SRSs in her classroom: "Students are always with their phones, tablets, laptops, and they are living with multimedia tools in the classrooms."

\section{Intention}

Most of the faculty members noted their intention to integrate technology in their current and future classes. They emphasised their willingness to integrate technologies more frequently in designing a new course or restructuring those they had already created. For instance, Baki remarked, "I use Facebook, intensively. In the beginning, I had ethical concerns, but I wanted to try. I realised that it worked then I continued to integrate it". One of the faculty members, Pelin, who self-rated as skillful on technology integration, stated, "I was unwilling to incorporate technology when I felt uncomfortable" before she started to integrate technology as an expert. This avoidance suggests that enthusiasm and expertise with technology may result in the willingness to integrate it in classrooms.

In terms of technology integration, faculty members' perceptions related to their academic disciplines did not change. An evident shift in their perception of their technology expertise was observed when they participated in the programme. More experienced staff were more critical of the advantages of technology for their teaching. This may result from the differences between technology adoption levels of the faculty members, and not from their academic disciplines. 


\section{Attitude}

Most of the faculty members cited attitude towards technology as a crucial determinant of behaviour. The attitude was related to compatibility with the context $(n=13)$, easy use of technology $(n=11)$, enthusiasm and interest to learn and use technology $(n=10)$ and usefulness for both themselves and students $(n=8)$. Parallel to these attitude determinants, faculty members were generally concerned about students' expectations and familiarity with the technology as well as the contributions of technology to their learning objectives. As an illustration, Deva stated, "Students are open to using technology in the classroom even if they do not use it frequently in their daily lives".

\section{Subjective norms}

Subjective norms consisting of students, peers and administrators influenced faculty members' technology integration behaviour. The influence of peers $(n=15)$, availability of support through teaching assistants $(n=3)$, support of colleagues having expertise in technology $(n=3)$ and encouragement of previous advisor or instructors $(n=2)$ helped the faculty members to adopt technology integration. For 15 of the faculty members, students were the frequently cited influential group on behaviour because of students' familiarity with technology and interest in using it. This created demand to integrate technology from the perspective of the faculty members. Didem indicated, "I am hopeful with technology integration because it indicates to me that both students and their smartphone can be in class together".

Administrative influence stemmed from the new faculty orientation programme and the technology mentoring programme. Interestingly, eight of the faculty members argued about limited or missing support from the institution or administrators. Deva emphasised "I think the administration is not aware of what we are doing on technology integration". The faculty members sensed the need for support as incentives from the administration level to integrate technology. For example, Ela stressed that "If there is financial support from the institution, faculty members' motivation may increase".

$P B C$

The LMS, SRS, and some web pages and software were listed under facilitative technologies $(n=17)$. The faculty members noted that the presence of resources and opportunities exerted influence on determination of intention. Further, they argued that infrastructure such as the availability of a computer centre, instructional technology support office, computers and projectors in classrooms, wireless networks and devices influenced their decisions for technology integration. They preferred the Clicker system for enabling students to answer questions via text messages, which was appropriate for basic cell phones. For example, Banu and Suat preferred to use Clicker instead of Socrative, a digital assessment platform, because it did not require smartphones or, most importantly, an Internet connection. Faculty members identified anticipated obstacles, technical problems and tool unavailability as factors impeding technology use and facilitative resources $(n=15)$. However, faculty members noted that knowledge, expertise and being digital natives promoted self-efficacy $(n=13)$ on technology, as an enhancer of faculty members' technology integration. For example, Baki claimed:

I can say that I have a positive attitude toward technology use and I think it is an essential tool for all of us. Additionally, I and my generation experienced the emergence of social media and YouTube. Our students were born in this technology-rich environment.

Within the programme, faculty members explored several technologies and implemented most of them. Although hesitant, with the encouragement of the mentors, they had the opportunity to try new technologies. Thus, they acquired expertise in technology integration and enthusiasm to use technology in their future courses, which indicates a shift in their intention as a result of the programme. Moreover, they gained expertise in choosing technologies by analysing their advantages and disadvantages. Ultimately, they also had the opportunity for self-development in readiness for current and future technology integration practices. The programme helped the faculty members develop their technology integration behaviour, attitude, subjective norms and perceived behaviour control. Faculty members emphasised three antecedents of the intention: student influence, self-efficacy and initial support of their mentors or assistants. Finally, the amount of time to learn how to implement, design and arrange the classroom environment in terms of technology integration, which could be a dimension of facilitative conditions, was the main concern of the faculty members. 


\section{Challenges and solutions}

Among the faculty members, 14 of them identified several challenges in technology integration categorised as student-related, instructor-related and context-related.

Student-related challenges were listed as student motivation, familiarity and enthusiasm. Students' eagerness and positive attitude propelled their need to integrate technology in their classrooms. For example, Pelin stated, "No matter whatever you make the technology-integrated activity, essential requirement of it is student motivation." On the other hand, faculty members noted that students' habits of technology use could pose a challenge if they were not familiar with a specific technology that the faculty intended to use in class. Furthermore, for the faculty members, students considered the instruction to learn new technology as an extra workload. For instance, Ela indicated, "The most important obstacle is that students do not even check their inboxes ... If they are not interested in technology, it is hard to deliver the content with technology".

The analysis also revealed that instructor-related challenges caused difficulty in implementing technologyenhanced instruction. The most commonly mentioned challenge was time limitation. The faculty members reported not having sufficient time to learn and integrate technology. For them, a preparatory process is necessary. Sadi affirmed:

It is necessary to allocate time for technology integration... There are two points: the first one is that I have to be well-prepared at least one day before the instruction. However, we do not have such a long time for preparation. Secondly, revision of materials also requires time and familiarity with technology.

The faculty members claimed that technology integration not only requires the additional time of instructional preparation but it also entailed a potential loss of class time. They noted that technical difficulties or malfunction could consume more time than intended during instruction. In addition to time, they mentioned having technological knowledge, being familiar with technology and finding the exact tools and resources to meet specific needs as sometimes challenging . For example, Seda indicated:

The most challenging part is to choose the appropriate technology for the content. Moreover, we are almost novice faculty members; we spend all our energy to prepare the content, and wecannot deal with the content delivery method. We do not have enough time, so we are moving like a baby.

Additionally, they reported that these difficulties created concerns regarding the management of technology-integrated classes, such as loss of students' attention and classroom control. Finally, faculty members' lack of motivation to integrate technology, especially with the absence of external motivators, surfaced as a critical factor. Suat pointed out the problem: "Although technology integration requires effort and time, it is not attractive and supported by the institution. Therefore, we do not have motivation for it".

Context-related challenges encompassed general technical difficulties, such as a slow or no Internet connection, hardware failures, large class size and inappropriate physical classroom environments. Pelin stated, "I have to check the projector in class each week, whether it works or it is broken, which makes me demoralised. After a while, I did not want to use this technology".

More importantly, digital devices were needed to integrate technology in class. Some programmes in particular required smartphones, which were not accessible to all students in the class. Suat specified, "I want to use technologies in my class, but some of the students may not have their own devices with them." This deficiency resulted in significant setbacks and compelled the instructor to resort to a backup plan, such as using paper-based instead of technology-supported activities. The finding for more support from assistants or other personnel who could help to find new technologies was another challenge for the faculty members. For example, Yade stated, "We could integrate technology more actively. However, we lacked assistants ... Socrative, a classroom management app, for instance, did not allow teachers to ask students open-ended questions, but it was useful for multiple-choice or short answer questions". 
The participants' suggestions to improve their technology integration efforts were categorized into PD, support and collaboration. Recommendations included more PD opportunities for them and their peers who did not join the technology mentoring programme. Seven of the faculty members pointed out that regular seminars were needed to acquaint them with new technologies, as well as increase faculty members' awareness of technology integration. Didem stated, "Seminar series provide opportunity to familiarise all faculty members with technology and make them up-to-date about educational technologies available for them."

Regarding support, seven of the faculty members suggested encouraging those who did not prefer to use or rarely used technology for educational purposes, combining technology with existing instructional practices and changing their attitudes towards this integration. From Banu's perspective, asking a question about LetsFeedback, a student response platform that enables instructors to engage students by asking online questions, required at least some degree of acquaintance with the platform.

Another recommendation of the faculty members was for more technical service facilities, such as a comprehensive information technology support team for troubleshooting hardware and software failures, as well as qualified teaching assistants or mentors for individual needs.

The faculty members also suggested collaborative approaches. They emphasised sharing samples of relevant classroom practices, cooperation among peers from same or different departments to share and exchange views and opinions on challenges and proposed solutions to difficulties. These were regarded as improvements to accustom faculty members to technology use as well as reinforce their planned technology integration behaviour. For example, interaction with peers who were practising technology integration made faculty members more active in technology integration, as informed by Ali and Baki. According to participants, the institution had an important role in solving technology integration problems of faculty members by facilitating more university-wide PD opportunities, improving available technology plans and supplying advanced digital devices to fulfill the goal of technology integration. They suggested that the university needed to take measures in providing external motivators to encourage faculty members who were passionate but were, unfortunately, struggling to adopt educational technology due to a lack of proper infrastructure and incentives.

\section{Perspectives on the technology mentoring programme}

The faculty members' perspectives on the technology mentoring programme can be categorised into contributions of the technology mentoring programme $(n=17)$ and suggestions for the development of the programme $(n=14)$. The programme provided faculty members the opportunity to explore and integrate some technologies with mentor support. They identified the following contributions of technology to their courses: moving learning out of classroom; making communication easy; reaching everyone easily; meeting students' and instructors' needs; creating a joyful environment for students; making learning easy; increasing motivation, awareness, and permanence of learning; practice opportunities; and promoting socialisation.

Regarding the programme's contribution, 10 of the faculty members stressed their influence on peers after the programme. Once they experienced technology integration professionally, they started to inform and direct their peers to integrate technology into their classrooms. For example, Seda, who was using Twitter in her classrooms, shared the class hashtag with her peer, who then wanted to try it in their classroom indicating the diffusion of the programme's effect on the departments.

Furthermore, seven faculty members emphasised mentors' support by contributing to not only their technological knowledge but also their pedagogical practices. With the programme, the faculty members' awareness and motivation increased through learning various types of educational technologies and increased awareness of the existence of many technologies to be explored for solving their instructional problems. They remarked that with the help of the individualized activities, the programme extended their vision on educational technology and increase their teaching effectiveness. For example, Yade indicated, "Because the programme was individualised for each instructor, it continued in the direction of his or her demands and needs". 
Most of the faculty members' evaluative comments on the technology mentoring programme concentrated on the contribution to their practice, the advantages of mentor guidance in teaching, the effects of specific digital tools and changes in their teaching style. Overall, faculty members agreed that it contributed positively to their development of technology integration by influencing their pedagogical approaches.

Among the participants, 12 faculty members had suggestions for improvement, which focused on publicising the technology mentoring programme in the university, enriching the programme with recurring technology workshops, arranging regular mentee-mentor meetings and classroom visits of mentors, improving matching strategy to reach more adequate pairing, including not only faculty members but also their teaching assistants in the programme, creating a community of practice in which all mentors and mentees could participate and involving all faculty members, not only the volunteers but also those who needed more support.

To analyse faculty members' planned technology integration behaviour within the context of the programme, the results indicate that the behaviour was highly affected by PBC, subjective norms and attitude. Besides, intention was clearly a less efficient factor for the behaviour. While all of the faculty members suffered from the challenges of technology integration, most of them suggested possible solutions for their challenges. Furthermore, they stressed the contributions of the programme to the behaviour by proposing some suggestions to implement an effective technology mentoring programme. Figure 2 illustrates the summary of results.

\begin{tabular}{|l|}
\hline \multicolumn{1}{|c|}{ Challenges } \\
Instructor-related \\
- Time \\
- Technological knowledge \\
- Classroom management \\
- Lack of motivation \\
Content-related \\
- Technical difficulties \\
- Physical environment \\
- Infrasturucture \\
- Support \\
Student-related \\
- Motivation \\
- Familiarity \\
- Enthusiasm
\end{tabular}


Figure 2. Overall faculty members' planned technology integration behaviour in the faculty technology mentoring programme

Discussion

This study aimed at exploring faculty members' technology integration behaviour in the context of a technology mentoring programme at a large public university in Turkey. This study contributes to the limited literature on explaining faculty members' technology integration behaviour and understanding the factors affecting the behaviour in a faculty technology mentoring programme as PD. According to findings of the study, faculty members mentioned the effect of all dimensions of the behaviour. The findings confirm the notion that all facets referred by DTPB could explain users' behaviour (Paver et al., 2014; Taylor \& Todd, 1995) from the perceptions of the faculty members, which is not actual measure of their behaviour.

Additionally, as a nature of the qualitative study, results mainly comprise self-reported data. Technology integration contributions and challenges generally shape conceptualisation and practice of technology integration among faculty members. The results indicated that faculty members who participated in the programme practised technology integration and developed their intention to integrate technology. Practising technology integration has a substantial positive effect on the teaching and learning process in higher education and results in increased motivation and enthusiasm. 
This study aimed at understanding the technology integration behaviour through the lens of DTPB: attitude towards technology integration, subjective norms and perceived behaviour control. Because DTPB is an extended version of the technology acceptance model (Taylor \& Todd, 1995), it helped to explain its components in detail. The faculty members' technology integration behaviours were supported by the factors described in the theory. The faculty members' perceived compatibility with the context of the courses (e.g., class size, course content) and easy usage of the technology directed their attitude towards technology integration behaviour. According to the perspectives of faculty members, technology integration implementation changes according to the size of the class, students' needs and desires. For example, faculty members do not prefer to integrate some technologies in larger classes (Peluchette \& Rust, 2005). The main purpose for using technology is to ease the instructional load, which is not compatible with larger class sizes.

\section{Behaviour}

The results of the study emphasised that the behaviour of faculty members is directly related to intention and intention and has antecedents such as attitude, student influence, subjective norm, self-efficacy and facilitative conditions. Among these antecedents, attitude, subjective norm and facilitative conditions have their own sub-dimensions. When compared to DTPB, subjective norms have a new dimension named as interest. Interest is accepted not only as an obstacle but also as a motivational factor in integrating technology in higher education (Mohammadzadeh et al., 2012). Because of this two-dimensional role of interest on technology integration, it is considered as a sub-dimension of attitude.

\section{Subjective norms}

Subjective norms of the faculty members were peer influence, administrator influence and assistant influence as sub-dimensions. When compared to DTPB, assistant influence is seen as a new dimension of subjective norms in this study. In the context of the study, the faculty members were teaching with the help of their assistants (mentors and teaching assistants) from planning to evaluating their courses. The teaching assistants help to reduce students' cognitive load and affect their engagement in technology-integrated courses (White et al., 2010), which decreased the faculty members' teaching and classroom management load.

Within the technology mentoring programme, the mentors were accepted as change agents who are the main actors of the programme for faculty members' practices of teaching with technology. In line with the study of Baran (2016b), mentors were motivated to assist in changing the pedagogy of faculty members. By reconstructing their pedagogical approaches, faculty members observed changes in their classrooms, namely an increase in student engagement, motivation, and communication; support of students' learning outside the classroom walls with the help of technology; and advancement of permanence of learning via facilitation. Moreover, the faculty members acted as experts while they interacted with their colleagues indicating learning transmission to their peers and diffusion of the programme's contributions to the university. By supporting the social connectedness of the students and faculty members (Hung \& Yuen, 2010), technology integration made learning experiences more favourable. Salajan et al. (2015) confirmed the expert role of faculty members who learned the LMS and started to use it. The programme focuses on the individuality of faculty members. Their perspectives indicate a need for enriching the programme with workshops in order to contribute in creating a learning community.

While the support of the individuals close to the faculty members contributes to the intention and behaviour, administrators had limited or no influence on the intention and behaviour of the faculty members, except for institutional facilities. The behaviour performance of the faculty members depends on the support from colleagues, peers and assistants, which is parallel to previous studies in which the most influential group was students (Salajan, et al. 2015). Prior research has highlighted the impact of student influence as a predictive factor of technology integration behavior (Ajjan \& Hartshorne, 2008; Hartshorne \& Ajjan, 2009; Lee et al., 2010; Paver et al., 2014). On the other hand, there is limited or no influence of administrators on the behaviour except for the facilities provided by the institution. This is supported by the study of GannonCook et al. (2009), who found that "faculty members wanted their basic physiological needs met by university administration through extrinsic motivators, such as salary increases and course releases" (p. 149). Reinforcing the development of positive attitudes might be critical to advancing the agenda. 
Faculty members' technology integration behaviour was commonly based on PBC, defined by selfefficacy, and facilitative resources and facilitative technologies (students' devices, instructor's technologies, infrastructure supported by institution, technology knowledge, technological support personnel and confidence in technology), which are confirmed by the literature (Buchanan et al., 2013; Hsu \& Chiu, 2004). As a facilitative condition, lack of time to learn new technologies (Butler \& Sellbom, 2002) and insufficient time for planning technology-integrated instruction (Earle, 2002; Ertmer, 1999) are crucial to instructional planning and implementation of technology-integrated courses. This was confirmed by the study of Salajan et al. (2015), which clarified that time constraint is an important determinant of the performance of faculty members' technology integration. Faculty members in the programme, however, suffer from not having enough time to think, plan, implement and evaluate technology-integrated courses (Watlington et al., 2014), because of their many responsibilities, including teaching, research, administration and management (Oshagbemi, 2000).

Technology integration behaviour of faculty members highly depends on proper settings and elimination of the inhibitor factors of technology use. It seems that an increasing success rate related to overcoming challenges contributes to self-efficacy, which is directly related to motivation. An optimistic perspective and attitude help faculty members to surmount hindrances, resulting in increased self-efficacy and motivation (Youssef, 2012), which arises from experiencing the productive impact of technology on teaching and learning within the technology mentoring programme context. Practice-oriented and contextoriented arrangements (Lukaš, 2014) support learning and practising technology integration of the faculty members in the programme. Mentoring as a PD activity is equally important, according to the results, by providing a chance to interact with experts to solve the unique needs of the faculty members.

As facilitative conditions, technologies and resources are represented in the DTPB separately. In this study, faculty members referred to time as an additional sub-dimension of facilitative conditions. Because it is both an inhibitor and enabler, time plays crucial role in behaviour. They perceived technology integration as time-consuming at the beginning and time-saving after being acquainted with the technology. Faculty members have to spend all their time in fulfilling their teaching and research responsibilities and they have limited time to devote to experiencing new educational technologies (Morales \& Roig, 2002). From the instructional perspective, course design and implementation need a considerable amount of time as well as both learning and implementing technology in the course (Davies et al., 2013). Therefore, time is considered as one of the factors affecting faculty members' technology integration behaviour during the programme.

As literature suggests, faculty members' technology integration behaviour is commonly based on PBC characterised by self-efficacy, facilitative resources and technologies (Buchanan et al., 2013). As a facilitative condition, not having enough time to learn new technologies (Butler \& Sellbom, 2002) and to integrate technology and pedagogy (Earle, 2002) is crucial for planning and implementing technologyintegrated courses. This was confirmed by the study of Salajan et al. (2015), which clarified that time constraints are important determinants of the performance of faculty members' technology integration. Faculty members in the programme, moreover, suffer from lack of time to think, plan, implement and evaluate technology-integrated instruction (Watlington et al., 2014) due to their responsibilities to teach, research, advise students and contribute to society. Within the context of this study, the technology-rich environment and self-confidence on technology integration affected faculty members' behaviour, positively, during the programme. A summary of the results related to the factors can be seen in Figure 3. 


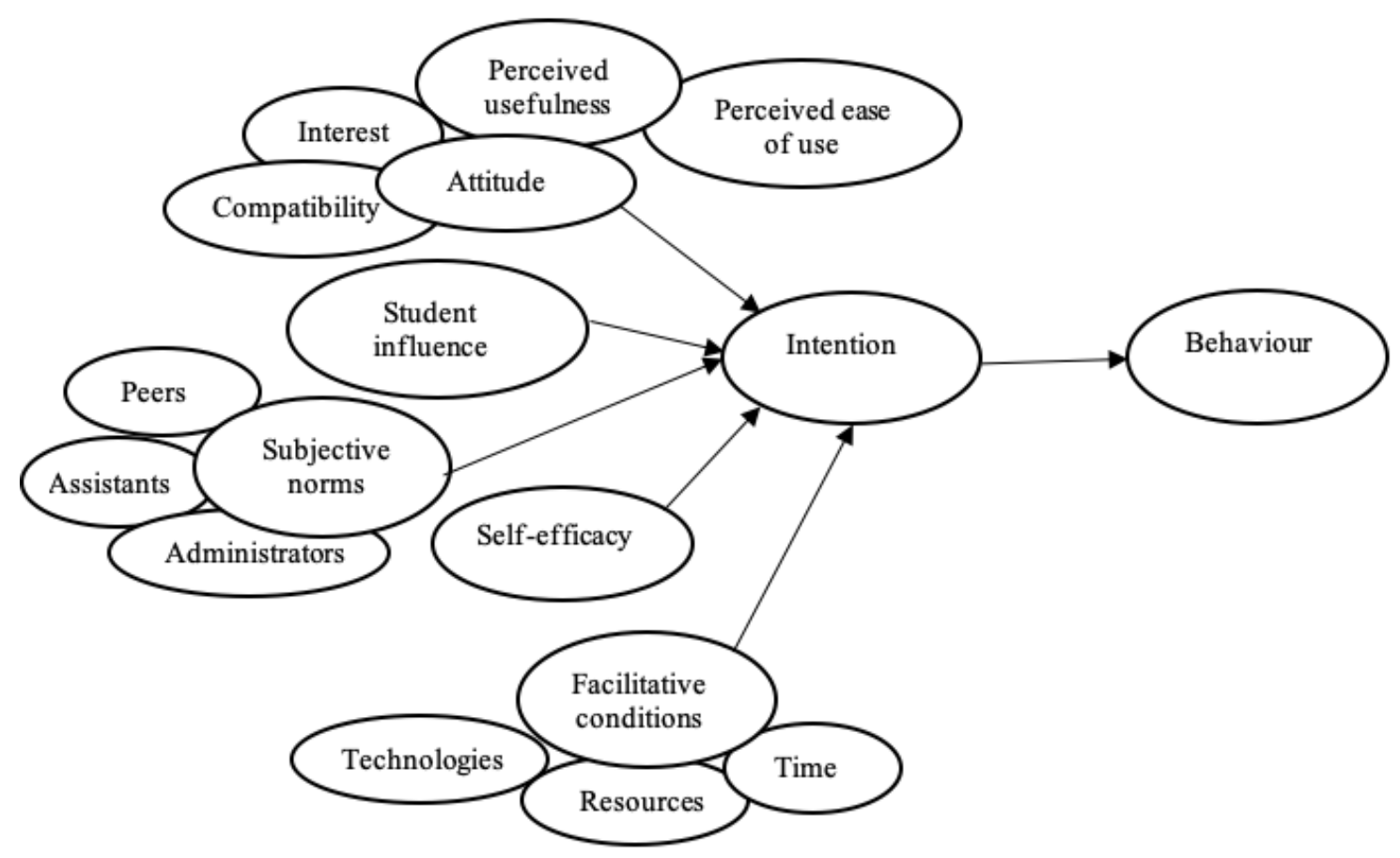

Figure 3. Factors affecting faculty members' technology integration behaviour

Mentoring programmes suggest similar results on faculty technology behaviour. For example, Leh (2005) conducted research in the United States of America and found time constraint as the main challenge for faculty members, who reported the need for organisational change and administration involvement to intensify the impact of faculty technology mentoring on student learning. With the help of the mentoring programme, faculty members' course design and instructional practice were affected positively (Buckenmeyer et al., 2013). These kinds of programmes implemented in other contexts indicate similar results on technology integration behaviour.

In an attempt to reach the purpose of this study, the perspectives of the faculty members in the programme to enrich their technology integration behaviour were crucial and helpful. Observing the faculty members who were in the process of learning how to efficiently perform the behaviour makes the results meaningful. This behaviour was affected by all the factors outlined by the DTPB. The faculty members also explained the challenges they faced, their solutions for the problems and suggestions to improve the technology mentoring programme.

\section{Conclusions and recommendations}

To progress in many aspects of our present-day technology-driven world, faculty members should develop a deeper understanding of teaching practices with technology (Georgina \& Hosford, 2009). This study demonstrates a way of understanding behaviour and helps to develop their behaviour with the help of the mentoring programme. The programme and technology integration provide opportunities to improve the faculty members' pedagogical practices with technology and give students equal opportunities to use it. Furthermore, some elements are needed to design more supportive and technology-rich teaching and learning environments. Creating a higher education environment supporting faculty members' development on technology integration is critical to improving technology-integrated practices in higher education.

The mentoring programme was implemented one-to-one, which has its own advantages and disadvantages. It can be cumbersome to implement in institutions with larger faculty presence. The programme could be implemented with the help of previous beneficiaries. These could be departmental leaders or information technology experts in terms of the technology mentoring endeavours. 


\section{Implications for research}

The factors affecting the technology integration behaviour of faculty members in the context of the technology mentoring programme were intention, attitude, subjective norms and PBC. Although intention is only directly related with behaviour in DTPB, it was a disregarded factor. Future research could focus on the reasons for it. Faculty members' emphasis on self-efficacy, student influence and facilitative conditions shows that these factors are needed to be directly related to intention towards behaviour rather than indirectly. Moreover, time for and with technology integration was highlighted by the faculty members. Thus, more studies on time as a subcomponent of technology integration behavior are needed. The behaviour could be analysed in similar context by pre- and post-interviews to define the actual change on the behaviour. On the other hand, different data collection techniques such as observation and students' views on faculty members' technology integration behaviour after a mentoring programme could be used to analyse the behaviour during the programme.

\section{Implications for practice}

Challenges can sometimes impede faculty members' technology integration. Faculty members, during and after faculty technology mentoring programmes, face challenges such as lack of time and motivation, insufficient technological knowledge and classroom management problems. Decreasing their heavy workload, such as administrative tasks or paperwork, enhancing opportunities (establishing a support office, providing departmental troubleshooting personnel, conducting seminars, providing more technical opportunities) and promoting integration behaviour (extrinsic motivation, extra promotion) could help them in increasing their technology knowledge and overcoming the challenges.

The results suggest improving the process for implementation the technology mentoring programme; revising the teaching and learning environment with the support of administrators, peers and students; increasing the awareness of the faculty members to integrate technology; and providing time and incentives to integrate technology.

\section{Limitations of the study}

This study has some limitations. Firstly, as data collection, the interview was conducted at the end of the programme and not conducted before it started. To control this limitation to some level, the participants were asked about their previous educational technology integration experiences. The number of participants were 17, which could be thought a limitation. However, this number is adequate for qualitative research. Additionally, participant selection was based on participants' willingness, which could be seen as limitation. However, in the nature of qualitative study, the main point in participant selection is voluntary participation and intentional selection of the participants to catch in-depth and accurate data from the participants. Finally, this study was conducted at a specific university. Indeed, this university was chosen because of its concurrent opportunities and infrastructure for the use of both faculty members and students.

\section{References}

Ajjan, H., \& Hartshorne, R. (2008). Investigating faculty decisions to adopt Web 2.0 technologies: Theory and empirical tests. The Internet and Higher Education, 11(2), 71-80. https://doi.org/10.1016/j.iheduc.2008.05.002

Ajzen, I. (1991). The theory of planned behavior. Organizational Behavior and Human Decision Processes, 50(2), 179-211. https://doi.org/10.1016/0749-5978(91)90020-T

Ajzen, I. (2002). Perceived behavioral control, self-efficacy, locus of control, and the theory of planned behavior. Journal of Applied Social Psychology, 32(4), 665-683. https://doi.org/10.1111/j.15591816.2002 tb00236.x

Amoako-Gyampah, K. (2007). Perceived usefulness, user involvement and behavioral intention: An empirical study of ERP implementation. Computers in Human Behavior, 23(3), 1232-1248. https://doi.org/10.1016/j.chb.2004.12.002

Atsoglou, K., \& Jimoyiannis, A. (2012). Teachers' decisions to use ICT in classroom practice: An investigation based on decomposed theory of planned behavior. International Journal of Digital Literacy and Digital Competence, 3(2), 20-37. https://doi.org/10.4018/jdldc.2012040102

Bandura, A. (1997). Self-efficacy: The exercise of control. W. H. Freeman and Company. 
Baran, E. (2016a). Investigating faculty technology mentoring as a university-wide professional development model. Journal of Computing in Higher Education, 28(1), 45-71. https://doi.org/10.1007/s12528-015-9104-7

Baran, E. (2016b). Examining the benefits of a faculty technology mentoring program on graduate students' professional development. Journal of Digital Learning in Teacher Education, 32(3), 95-104. https://doi.org/10.1080/21532974.2016.1169958

Buabeng-Andoh, C. (2012). Factors influencing teachers' adoption and integration of information and communication technology into teaching: A review of the literature. International Journal of Education and Development Using Information and Communication Technology, 8(1), 136-155. http://ijedict.dec.uwi.edu/viewarticle.php?id=1361

Buchanan, T., Sainter, P., \& Saunders, G. (2013). Factors affecting faculty use of learning technologies: Implications for models of technology adoption. Journal of Computing in Higher Education, 25(1), 111. https://doi.org/10.1007/s12528-013-9066-6

Buckenmeyer, J., Hixon, E., Barczyk, C., \& Feldman, L. (2013). Does participation in a faculty distance education mentoring program comprehensively improve teaching methods? International Journal on E-Learning, 12(2), 139-152. https://www.learntechlib.org/primary/p/36086/

Burnaford, G. (2001). Teacher's work: Methods for researching teaching. In G. Burnaford, J. Fischer \& D. Hobson (Eds.) Teachers doing research: The power of action through inquiry (pp. 49-82). Lawrence Erlbaum Associates.

Butler, D. L., \& Sellbom, M. (2002). Barriers to adopting technology. Educause Quarterly, 2, 22-28.

Chuang, H. H., Thompson, A., \& Schmidt, D. (2003). Faculty technology mentoring programs: Major trends in the literature. Journal of Computing in Teacher Education, 19(4), 101-106. https://doi.org/10.1080/10402454.2003.10784472

Cilsalar, H. (2017). Investigating faculty members' technology integration intention and behavior: A case of a higher education institution [Doctoral dissertation, Middle East Technical University]. https://tez.yok.gov.tr/UlusalTezMerkezi/TezGoster?key=RrI-Krk3A-RkF4YfHofukynxyxzQ9xtXYqzuuNPdYwb1FlaP aWZvijW4ejiuol

Creswell, J. W. (2007). Qualitative inquiry and research design: Choosing among five approaches (2nd ed.). Sage Publications.

Davies, R. S., Dean, D. L., \& Ball, N. (2013). Flipping the classroom and instructional technology integration in a college-level information systems spreadsheet course. Educational Technology Research and Development, 61(4), 563-580. https://doi.org/10.1007/s11423-013-9305-6

Davis, F. D. (1989). Perceived usefulness, perceived ease of use, and user acceptance of information technology. MIS Quarterly, 13(3), 319-340. https://doi.org/10.2307/249008

Desimone, L. M., \& Garet, M. S. (2015). Best practices in teachers' professional development in the United States. Psychology, Society and Education, 7(3), 252-263. https://doi.org/10.25115/psye.v7i3.515

Dupin-Bryant, P. A. (2012). Faculty perceptions of pedagogical benefits of Web 2.0 technologies and variables related to adoption. Issues in Information Systems, 13(1), 258-263. https://iacis.org/iis/2012/57 iis 2012 258-263.pdf

Earle, R. S. (2002). The integration of instructional technology into public education: Promises and challenges. Educational Technology, 42(1), 5-13. http://www.jstor.org/stable/44428716

Ertmer, P. A. (1999). Addressing first- and second-order barriers to change: Strategies for technology integration. Educational Technology Research and Development, 47(4), 47-61. https://doi.org/10.1007/BF02299597

Gannon-Cook, R., Ley, K., Crawford, C., \& Warner, A. (2009). Motivators and inhibitors for university faculty in distance and e-learning. British Journal of Educational Technology, 40(1), 149-163. https://doi.org/10.1111/j.1467-8535.2008.00845.x

Georgina, D. A., \& Hosford, C. C. (2009). Higher education faculty perceptions on technology integration and training. Teaching and Teacher Education, 25(5), 690-696. https://doi.org/10.1016/j.tate.2008.11.004

Gikas, J., \& Grant, M. M. (2013). Mobile computing devices in higher education: Student perspectives on learning with cellphones, smartphones \& social media. The Internet and Higher Education, 19, 18-26. https://doi.org/10.1016/j.iheduc.2013.06.002

Gunuc, S. (2015). Implementation and evaluation of technology mentoring program developed for teacher educators: A 6 M-framework. Qualitative Research in Education, 4(2), 164-191. https://doi.org/10.17583/qre.2015.1305

Hartshorne, R., \& Ajjan, H. (2009). Examining student decisions to adopt Web 2.0 technologies: Theory 
and empirical tests. Journal of Computing in Higher Education, 21(3), 183-198. https://doi.org/10.1007/s12528-009-9023-6

Hassad, R. A. (2013). Faculty attitude towards technology-assisted instruction for introductory statistics in the context of educational reform. Technology Innovations in Statistics Education, 7(2). https://escholarship.org/uc/item/9k19k2f7

Hsu, M. H., \& Chiu, C. M. (2004). Internet self-efficacy and electronic service acceptance. Decision Support Systems, 38(3), 369-381. https://doi.org/10.1016/j.dss. 2003.08.001

Hung, H., \& Yuen, S. C. (2010). Educational use of social networking technology in higher education. Teaching in Higher Education, 15(6), 703-714. https://doi.org/10.1080/13562517.2010.507307

Inan, F. A., \& Lowther, D. L. (2010). Factors affecting technology integration in K-12 classrooms: A path model. Educational Technology Research and Development, 58(2), 137-154. https://doi.org/10.1007/s11423-009-9132-y

Johnson, W. B. (2015). On being a mentor: A guide for higher education faculty. Routledge.

Jordan, K. (2014). Initial trends in enrolment and completion of massive open online courses. The International Review of Research in Open and Distributed Learning, 15(1), 133-160. https://doi.org/10.19173/irrodl.v15i1.1651

Kirkwood, A., \& Price, L. (2013). Missing: Evidence of a scholarly approach to teaching and learning with technology in higher education. Teaching in Higher Education, 18(3), 327-337. https://doi.org/10.1080/13562517.2013.773419

Krippendorff, K. (2004). Measuring the reliability of qualitative text analysis data. Quality and Quantity, 38, 787-800. https://doi.org/10.1007/s11135-004-8107-7

Kurtts, S. A., \& Levin, B. B. (2000). Using peer coaching with preservice teachers to develop reflective practice and collegial support. Teaching Education, 11(3), 297-310. https://doi.org/10.1080/713698980

Larson, L. (2009). A descriptive study of mentoring and technology integration among teacher education faculty. International Journal of Evidence Based Coaching and Mentoring, 7(1), 119-135. https://core.ac.uk/download/pdf/132154321.pdf

Lee, J., Cerreto, F. A., \& Lee, J. (2010). Theory of planned behavior and teachers' decisions regarding use of educational technology. Educational Technology and Society, 13(1), 152-164. https://www.jstor.org/stable/jeductechsoci.13.1.152

Leh, A. (2005). Lessons learned from service learning and reverse mentoring in faculty development: A case study in technology training. Journal of Technology and Teacher Education, 13(1), $25-41$. https://www.learntechlib.org/primary/p/6565/

Lincoln, Y. S. (2007). Naturalistic inquiry. Sage. https://doi.org/10.1002/9781405165518.wbeosn006

Lori, L., Cronan, T. P., \& Kreie, J. (2004). What influences IT ethical behavior intentions - planned behavior, reasoned action, perceived importance, or individual characteristics? Information \& Management, 42(1), 143-158. https://doi.org/10.1016/j.im.2003.12.008

Lukaš, M. (2014). Supporting friendly atmosphere in a classroom by technology implementation. In E. Berbić Kolar, B. Bognar, M. Sablić, \& B. Sedlić (Eds.), Challenges in building child friendly communities: Proceedings of the International Conference (pp. 1-16). Europe House SlavonskiBrod.

Mak, J. Y., \& Ross, C. M. (2003). Using the theory of planned behavior to predict leisure educators' intentions to use instructional technology. Leisure/Loisir, 28(3-4), 307-328. https://doi.org/10.1080/14927713.2003.9651317

Marzilli, C., Delello, J., Marmion, S., McWhorter, R., Roberts, P., \& Marzilli, T. S. (2014). Faculty attitudes towards integrating technology and innovation. International Journal on Integrating Technology in Innovation, 3(1), 1-20. https://doi.org/10.5121/ijite.2014.3101

Mayes, R., Natividad, G., \& Spector, J. M. (2015). Challenges for educational technologists in the $21 \mathrm{st}$ century. Education Sciences, 5(3), 221-237. https://doi.org/10.3390/educsci5030221

Mohammadzadeh, M., Farzaneh, J., \& Mousavi, M. (2012). Challenges and strategies for e-learning development in The Payame Noor University of Iran. Turkish Online Journal of Distance Education, 13(1), 148-159. https://dergipark.org.tr/en/pub/tojde/issue/16899/176127

Morales, L., \& Roig, G. (2002). Connecting a technology faculty development program with student learning. Campus-Wide Information Systems, 19(2), 67-72. https://doi.org/10.1108/10650740210421881

Motta, M. (2016). A blended learning environment based on the principles of deliberate practice for the acquisition of interpreting skills. The Interpreter and Translator Trainer, 10(1), 133-149. https://doi.org/10.1080/1750399X.2016.1154347

Mouza, C. (2003). Learning to teach with new technology: Implications for professional development. 
Journal of Research on Technology in Education 35(2), 272-289. https://doi.org/10.1080/15391523.2002.10782386

O'Flaherty, J., \& Phillips, C. (2015). The use of flipped classrooms in higher education: A scoping review. The Internet and Higher Education, 25, 85-95. https://doi.org/10.1016/j.iheduc.2015.02.002

Oshagbemi, T. (2000). How satisfied are academics with their primary tasks of teaching, research and administration and management? International Journal of Sustainability in Higher Education, 1(2), 124-136. https://doi.org/10.1108/1467630010371876

Paver, J., Walker, D. A., \& Hung, W. C. (2014). Factors that predict the integration of technology for instruction by community college adjunct faculty. Community College Journal of Research and Practice, 38(1), 68-85 https://doi.org/10.1080/10668926.2013.799449

Peluchette, J. V., \& Rust, K. A. (2005). Technology use in the classroom: Preferences of management faculty members. Journal of Education for Business, 80(4), 200-205. https://doi.org/10.3200/JOEB.80.4.200-205

Prottas, D. J., Cleaver, C. M., \& Cooperstein, D. (2016). Assessing faculty attitudes towards online instruction: A motivational approach. Online Journal of Distance Learning Administration, 19(4). https://www.westga.edu/ distance/ojdla/winter 194/prottas cleaver cooperstein194.html

Rivera, J. H. (2017). The blended learning environment: A viable alternative for special needs students. Journal of Education and Training Studies, 5(2), 79-84. https://doi.org/10.11114/jets.v5i2.2125

Rogers, E. M. (1995). Diffusion of innovations. The Free Press.

Sadaf, A., Newby, T. J., \& Ertmer, P. A. (2016). An investigation of the factors that influence preservice teachers' intentions and integration of Web 2.0 tools. Educational Technology Research and Development, 64(1), 37-64. https://doi.org/10.1007/s11423-015-9410-9

Sahin, I., \& Thompson, A. (2007). Analysis of predictive factors that influence faculty members' technology adoption level. Journal of Technology and Teacher Education, 15(2), 167-190. https://www.learntechlib.org/p/18935/

Salajan, F. D., Welch, A. G., Ray, C. M., \& Peterson, C. M. (2015). The role of peer influence and perceived quality of teaching in faculty acceptance of web-based learning management systems. International Journal on E-Learning, 14(4), 487-524. https://www.learntechlib.org/primary/p/48018/

Sandelowski, M., Voils, C. I., \& Knafl, G. (2009). On quantitizing. Journal of Mixed Method Research, 3, 208-222. https://doi.org/10.1177/1558689809334210

Schoepp, K. W. (2004). Technology integration barriers in a technology-rich environment: A CBAM perspective [Master's dissertation, University of Calgary]. https://prism.ucalgary.ca/handle/1880/41974

Strauss, A. L., \& Corbin, J. (1990). Basics of qualitative research (Vol. 15). Sage Publications.

Taylor, S., \& Todd, P. A. (1995). Understanding information technology usage: A test of competing models. Information Systems Research, 6(2), 144-176. https://doi.org/10.1287/isre.6.2.14

Taylor, S. J., \& Bogdan, R. (2005). Introduction to qualitative research methods. John Wiley \& Sons.

Thompson, R. L., Higgins, C. A., \& Howell, J. M. (1991). Personal computing: Toward a conceptual model of utilization. MIS Quarterly, 15(1), 124-143. https://doi.org/10.2307/249443

Watlington, D., Murley, R., Cornelius, A., \& Kelley, T. (2014). Preparing educators for development of innovative teaching using mobile technology. In J. Keengwe (Ed.), Promoting active learning through the integration of mobile and ubiquitous technologies (pp. 74-97). Information Science Reference. https://doi.org/10.4018/978-1-4666-6343-5.ch005

White, C. R., Ramirez, R., Smith, J. G., \& Plonowski, L. (2010). Simultaneous delivery of a face-to-face course to on-campus and remote off-campus students. TechTrends, 54, 34-40. https://doi.org/10.1007/s11528-010-0418-z

Wixom, B. H., \& Todd, P. A. (2005). A theoretical integration of user satisfaction and technology acceptance. Information Systems Research, 16(1), 85-102. https://doi.org/10.1287/isre.1050.0042

Yin, R. K. (2003). Case study research: Design and methods, applied social research methods series. Sage Publications, Inc.

Youssef, A. M. S. (2012). Role of motivation and attitude in introduction and learning of English as a foreign language in Libyan high schools. International Journal of Linguistics, 4(2), 366-375. https://doi.org/10.5296/ijl.v4i2.1855 
Corresponding author: Hatice Cilsalar Sagnak, hatice.cilsalar@yobu.edu.tr; $\underline{\text { haticecilsalar@gmail.com }}$

Copyright: Articles published in the Australasian Journal of Educational Technology (AJET) are available under Creative Commons Attribution Non-Commercial No Derivatives Licence (CC BY-NC-ND 4.0). Authors retain copyright in their work and grant AJET right of first publication under CC BY-NC-ND 4.0.

Please cite as: Cilsalar Sagnak, H., \& Baran, E. (2021). Faculty members' planned technology integration behaviour in the context of a faculty technology mentoring programme. Australasian Journal of Educational Technology, 37(3), 1-21. https://doi.org/10.14742/ajet.5912 